\title{
A Spectrum Response Study on Single Strand DNA Breaks, Sister Chromatid Exchanges, and Lethality Induced by Phototherapy Lights
}

\author{
E. G. SIDERIS, ${ }^{(29)}$ G. C. PAPAGEORGIOU, SYLVA C. CHARALAMPOUS, AND EVA M. VITSA
}

Department of Biology, Nuclear Research Center, Demokritos, Aghia Paraskevi, Athens, Greece

\begin{abstract}
Summary
Little information is available on the effect of visible light from commercial fluorescence lamps, commonly used in the treatment of neonatal hyperbilirubinemia, on parameters related to genetic damage in eucaryotic cells. The present study was undertaken to determine whether or not visible light of different wavelengths had any differential effects on the frequency of DNA breaks (frank breaks plus alkaline labile lesions), DNA replication, frequency of sister chromatid exchanges, and survival in cultured Chinese hamster cells.

The results revealed that the "blue" spectral band $(420$ to 500 nm) is mainly responsible for DNA breaks, sister chromatid exchanges, and lethality induced by fluorescent light. This band is precisely that which bilirubin heavily absorbs and, hence, is the most efficient for the decomposition of this metabolite.

These results were obtained with the use of light doses of 5 to $30 \times 10^{4} \mathrm{~J} / \mathrm{m}^{3}$ versus the light doses of the order of $100 \times 10^{4} \mathrm{~J} /$ $\mathrm{m}^{2}$ being received by infants undergoing phototherapy treatment.

\section{Speculation}

In view of the close relationship between introduction of DNA lesions, the high frequency of induced sister chromatid exchanges, and the lethality on the one hand and the mutagenicity/carcinogenicity on the other, the results presented in this publication point against the wide use of fluorescent lamps emitting at the shorter wavelengths of visible light for phototherapy treatments.
\end{abstract}

Few publications present evidence indicating that visible light induces single-strand breaks (alkaline labile regions) in cultured mammalian tissue cells of DNA alkaline lysates $(6,9)$. Findings which indicate that visible light also induces changes in the DNA of cancerous cells led to the suggestion that phototherapy treatment of neonatal hyperbilirubinemia might be associated with serious long-term consequences (23).

These results are extremely interesting in view of certain recent experimental findings, following the original works by Hollaender (12), showing the mutagenic effects of visible light from commercial fluorescent lamps on mammalian cells $(3,11,14,19)$ because of the close association between the mutagenic and the carcinogenic properties of many agents (1).

Evidence has also been presented suggesting that radiation of wavelengths longer than $300 \mathrm{~nm}$ induced skin cancer in mice (8) and cataracts in man (27).

The present work attempts to elucidate which spectral region of light, emitted by commercial fluorescent lamps, is responsible for lesions assocaited with hereditary material in cultured mammalian cells. The need for a detailed study on the biologic effectiveness of the visible light spectrum has been pointed out by certain authors $(5,14)$. However, the possible involvement of ultraviolet radiant energy contamination in fluorescent light used in some of the above-mentioned experimental works has not been ruled out $(3,5,14,22,25)$.

In the present work, we measured the effect of light emitted from three regions of the visible spectrum by a commercial fluorescent lamp identical to those used in the treatment of hyperbilirubenemia as well as to those in offices and factories. The following parameters were used to evaluate the effects of different wavelengths: the frequency of sister chromatid exchanges, the relative changes in the molecular weight (MW) of DNA, the incorporation of radioactive thymidine, and cell survival.

Our results clearly show that the region of visible light spectrum more efficient for inducing alkaline labile DNA regions and sister chromatid exchanges, inhibition of DNA synthesis, and low survival is confined between 420 and $500 \mathrm{~nm}$.

\section{MATERIALS AND METHODS}

\section{CULTURED CELLS}

A clone of the V-79 aneuploid line from Chinese hamster (Cricetulus griseus), kindly supplied by Dr. C. Arlett, MRC Cell Mutation Unit, University of Sussex, was used in these experiments. The cells were cultured in polystyrene Petri dishes in Eagle's minimal medium with Earle's salts supplemented with $15 \%$ foetal bovine serum (CMEM). The cultures were incubated in the dark at $37^{\circ} \mathrm{C}$ in $\mathrm{CO}_{2}$ atmosphere.

\section{ALKALINE LABILE DNA LESIONS}

Radioactive thymidine $\left(18 \mathrm{Ci} / \mathrm{mmole}{ }^{3} \mathrm{H}\right)$ was added to the medium of the cultures to result in a final concentration of $1 \mu \mathrm{Ci}$ / $\mathrm{ml}$. The medium was brought up to $10 \mu \mathrm{M}$ of unlabeled thymidine. The cells after overnight incubation at log phase, were washed with phosphate-buffered saline (PBS) $\left(8 \mathrm{~g} \mathrm{NaCl}: 0.2 \mathrm{~g} \mathrm{KH}_{2} \mathrm{PO}_{4}: 0.2\right.$ g KCl:1.15 $\mathrm{g} \mathrm{Na}_{2} \mathrm{HPO}_{4}$ per liter). The washed cells were either scraped off with a piece of silicon rubber and suspended in $2 \mathrm{ml}$ of buffered EDTA solution (0.2 g EDTA in PBS) or covered in situ with $5 \mathrm{ml}$ of CMEM without phenol red (CMEM-PR).

Two hundred $\mu \mathrm{l}$ of the suspended cells containing about 20,000 cells were transferred to the top of 5 to $20 \%$ alkaline sucrose gradients in $0.1 \mathrm{~N} \mathrm{NaOH}: 0.9 \mathrm{~N} \mathrm{NaCl}$ overlaid with $0.2 \mathrm{ml}$ of 0.45 $\mathrm{N} \mathrm{NaOH}: 0.55 \mathrm{~N} \mathrm{NaCl}: 0.01 \mathrm{M}$ EDTA.

\section{ILLUMINATION}

Tubes with cell lysates on top of the sucrose gradient or Petri dishes with the cell tapetia, were exposed to fluorescent light from a FC12 T10 "daylight" lamp. The cell tapetia was covered with CMEM-PR and kept at $\mathrm{CO}_{2}$ atmospheres. All experiments were carried out at $4^{\circ} \mathrm{C}$ in a cold room.

After the exposure to light, the cell tapetia were washed in PBS and removed with $2 \mathrm{ml}$ of buffered EDTA solution. The 20,000 
cells from the suspension were transferred to the top of 5 to $20 \%$ sucrose gradients.

The emission spectrum of the lamp was kindly supplied by the Hellenic Commercial Electric Lamps Co., branch of the GTE Sylvania Co. (24). A series of Corning colored glass filters was used to isolate selected spectral bands of the emitted light. The emission spectrum of the lamp and the transmittance curves of the used filter combinations are shown on Figure 1. The transmittance curves of the filters were taken with a C.ry-14 Recording Spectrometer. The light intensity, at the plane of the menisci of the centrifuge tubes or of the tapetia in the Petri dishes, was measured with a 12-junction Bi-Ag Eppley thermopile whose output was monitored with a Keithley 150 B Ammeter-Voltometer. Care was taken to shield the tubes containing the lysates or the Petri dishes containing the cell tapetia from ambient light by wrapping them in aluminum foil.

Table 1 lists the radiation characteristics of the filter combinations used in this study. The mean energy $E$ of photons from the different sections of the spectrum was estimated in $\mathrm{kcal} /$ einstein, i.e., $\mathrm{kcal} / \mathrm{mole}$ of photons, from the formula $\mathrm{E}=2.86 \times 10^{4} / \lambda$ where $\lambda$ is the mean wavelength (in $m \mu$ ) of light transmitted through each filter combination (2).

Light of wavelengths 700 to $350 \mathrm{~nm}$ was uniformly transmitted through the polystyrene Petri dishes; light transmission falls

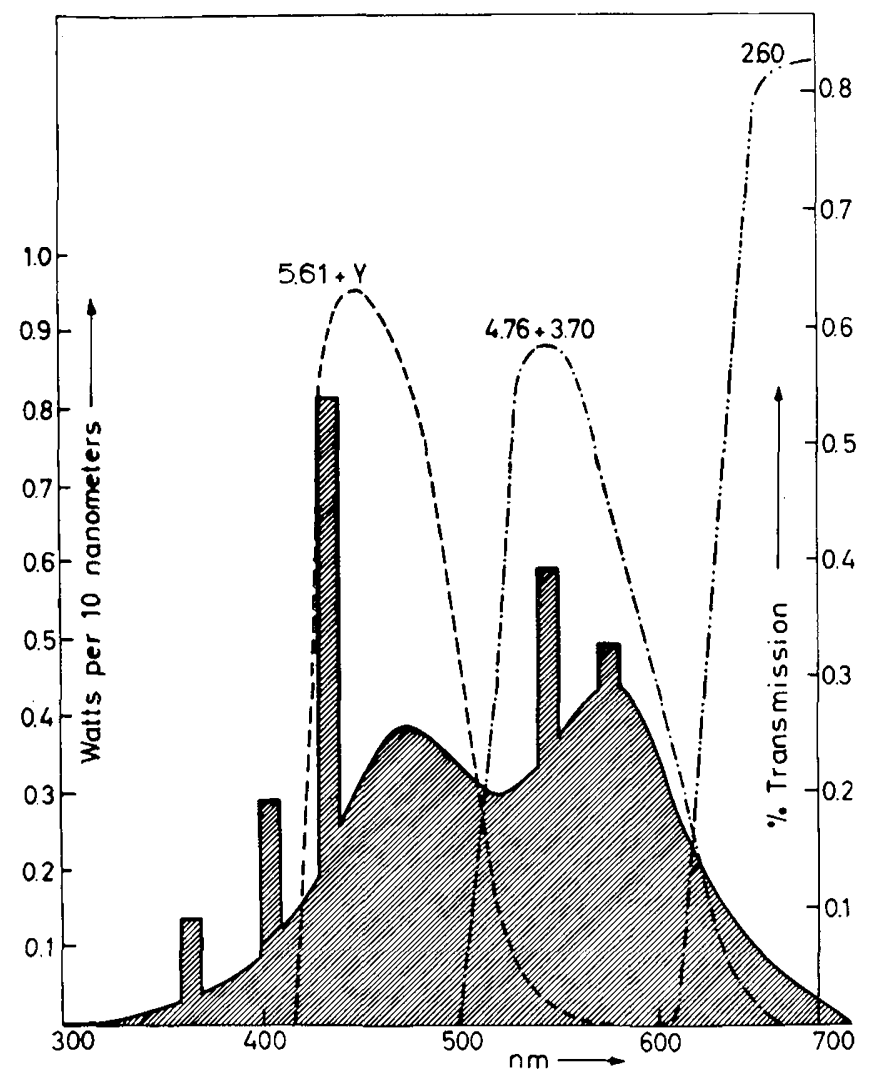

Fig. 1. Emission spectrum of the used "daylight" lamp and transmission spectra of the filters used.

Table 1. Radiation characteristics of the filter combinations used and corresponding incident light energy at the position of the exposure

\begin{tabular}{llc}
$\begin{array}{c}\text { Filter color } \\
\text { specification }\end{array}$ & $\begin{array}{c}\text { Transmitted } \\
\text { color }\end{array}$ & $\begin{array}{c}\text { Incident light } \\
\text { energy intensity } \\
\left(\mathrm{J}^{2} \mathrm{M}^{2} \mathrm{sec}\right)\end{array}$ \\
\hline $5.61+\mathrm{Y}$ & Blue & 3.61 \\
$4.76+3.70$ & Green & 4.03 \\
2.60 & Red & 3.46 \\
\hline
\end{tabular}

sharply to 0 between 300 and $280 \mathrm{~nm}$. Thus, the transmission of the fluorescent light emitted from the FC12T10 lamp (Fig. 1) was not differentially affected by the polystyrene of the Petri dishes.

\section{ULTRACENTRIFUGATION}

After exposure to light, the material was centrifuged for $60 \mathrm{~min}$ in a SW 50.1 rotor with an L75 Beckman Ultracentrifuge. Tubes containing material exposed to light in the form of cell alkaline lysates were run at $20,000 \mathrm{rpm}$ at $15^{\circ} \mathrm{C}$. Tubes containing material exposed to light in the form of cell tapetia were run at $38,000 \mathrm{rpm}$ at $20^{\circ} \mathrm{C}$. After centrifugation, seven-drop fractions were collected into Whatman $3 \mathrm{MM}$ paper strips. The acid-insoluble radioactivity of each fraction was measured as described previously (15). Relative MWs, i.e., the ratio of MW of the treated sample to the MW of the control $\left(\mathrm{MW} / \mathrm{MW}_{\mathrm{o}}\right)$ were estimated according to Palcic and Skarsgard (17).

\section{DNA REPLICATION}

Cell tapetia, at the $\log$ phase, were prepared in Petri dishes, rinsed in PBS, covered with CMEM-PR, and then exposed to light. Immediately after exposure, conditioned CMEM was substituted for CMEM-PR, and Petri dishes were transferred into an incubation champer. Radioactive thymidine $(1 \mu \mathrm{Ci} / \mathrm{ml})$ was added at $0,7,17,27$, and $41 \mathrm{hr}$ after the end of light exposure, and the cells were harvested $7 \mathrm{hr}$ after the addition of the radioactive thymidine, i.e., at the seventh, 14th, 24th, 34th, and 48th hr. The DNA content of the samples was measured according to Burton (4), and the radioactivity was measured in POPOP-PPO solution in toluene to which Triton- $X$ had been added as a solubilizer. The specific radioactivity was the estimated in $\mathrm{cpm} / \mu \mathrm{g}$ of DNA. Three replications per treatment were used.

\section{SISTER CHROMATID EXCHANGES}

Cells at the log phase were exposed to light and then incubated in the presence of $10 \mu \mathrm{M}$ bromodeoxyuridine for two life cycles period. Colcemid $\left(2 \times 10^{-7} \mathrm{M}\right)$ was added $3 \mathrm{hr}$ before the collection of cells with trypsinization. Then the cells were exposed to 0.075 $\mathrm{M} \mathrm{KCl}$ and fixed in 3:1 ethanol:acetic acid. The air-dried preparations were stained by the FPG procedure, and the harlequinstained chromosomes were scored (18).

\section{SURVIVAL}

After exposure to light, 100 cells per treatment per replication were seeded in $5 \mathrm{~cm}$ Petri dishes and left to grow into colonies in $\mathrm{CMEM}$ at $37^{\circ} \mathrm{C}$ in $\mathrm{CO}_{2}$ atmosphere for 10 days. Then the colonies were stained in situ with methylene blue and scored. Four replications per treatment were used.

\section{RESULTS AND DISCUSSION}

The results given in Figure 2 clearly indicate that alkaline cell lysates from V-79 cells are relatively more susceptible to the blue section of fluorescent light under exposures of $30 \times 10^{4} \mathrm{~J} / \mathrm{m}^{2}$. The parameter for measuring damage is single-strand DNA breaks (i.e., frank breaks plus alkali labile regions) (7).

Similar results were obtained when alkaline lysates were exposed to varying dosages of light energy (Fig. 3). Whereas DNA damage in cell lysates irradiated with red or green light tends to form a "plateau" after a $20 \times 10^{4} \mathrm{~J} / \mathrm{m}^{2}$ dosage of light energy, an apparently inverse linear relationship is present between blue light dosage in $\mathrm{J} / \mathrm{m}^{2}$ and DNA damage.

When living cells in the form of tapetia at the log phase were exposed to a dosage of $5 \times 10^{4} \mathrm{~J} / \mathrm{m}^{2}$, a parallel effect on the MW of DNA was found (Fig. 4). Although DNA sedimentation from cells exposed to red or green light was very close to that from cells not exposed to light, DNA sedimentation from cells exposed to blue light occurred at lighter aliquots.

In Figure 5, the damage to DNA in the form of frank breaks 


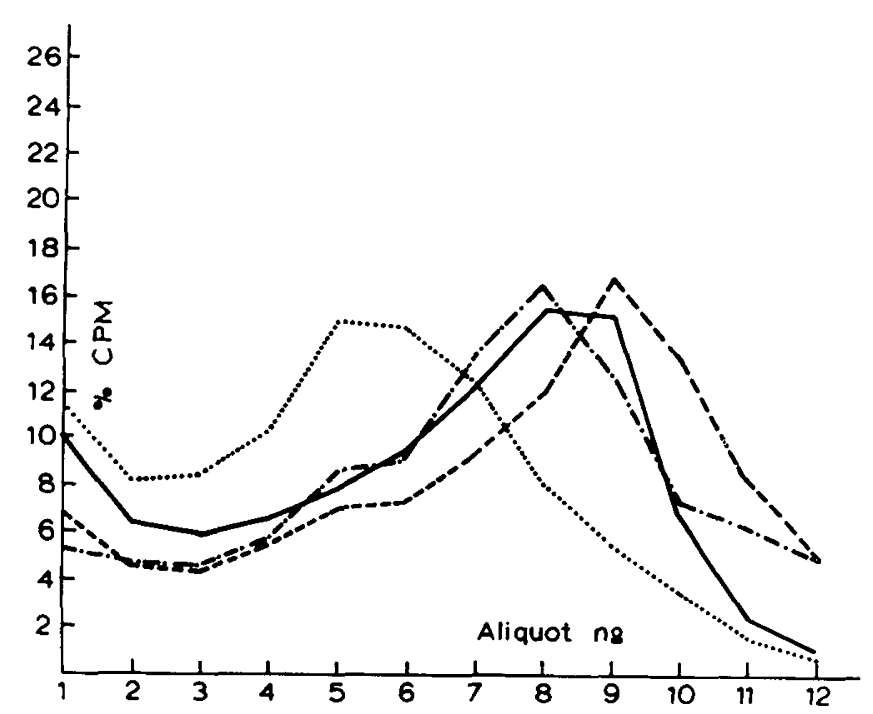

Fig. 2. Sedimentation profiles of DNA from cell alkaline lysates exposed to blue $(\cdots \cdots)$, green $(-)$, and red $(-\cdot-)$ spectral bands of fluorescent light $\left(30 \times 10^{4} \mathrm{~J} / \mathrm{m}^{2}\right)$. Dark control $(---)$.

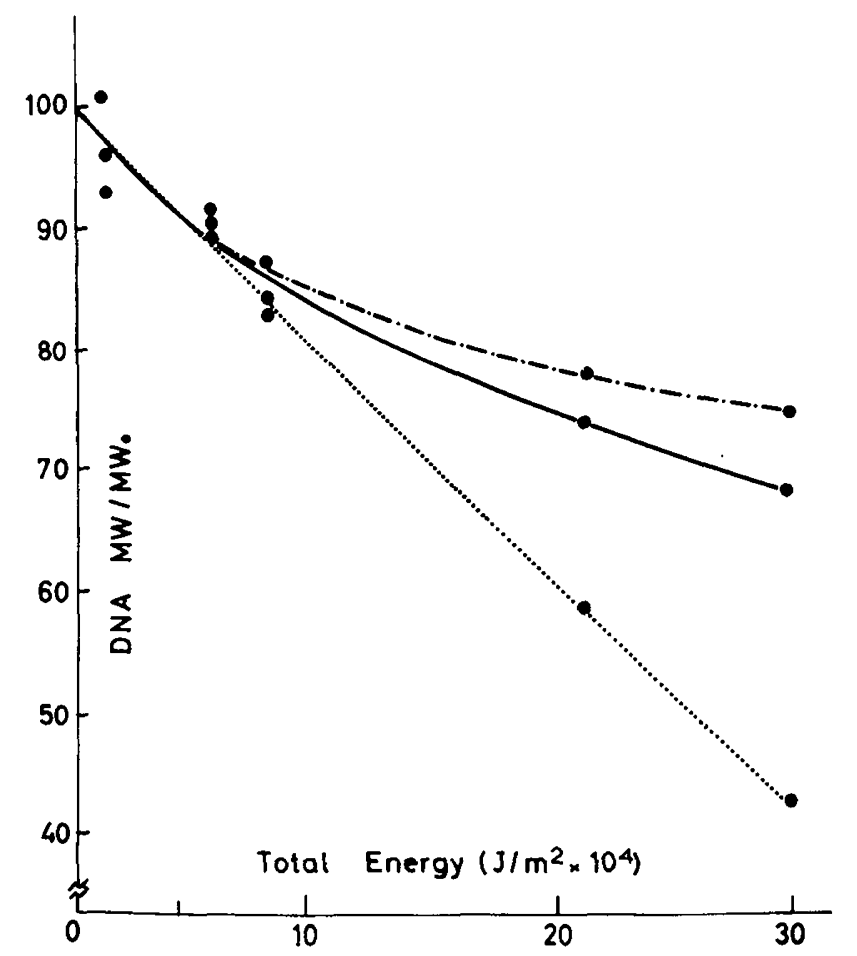

Fig. 3. The effect of the absorbed total energy from fluorescent light of blue $(\cdots \cdots)$, green $(-)$, and red $(-\cdots)$ spectral bands on the relative MW of DNA from cell alkaline lysates exposed to fluorescent light.

plus alkaline labile lesions is plotted against the absorbed quantum energy. These plots indicate a relationship between the quantum energy and the damage inflicted on the DNA molecule.

From these results, it can be concluded that the spectral band more efficient in introducing DNA single-strand breaks seems to be that range lying between 500 and $420 \mathrm{~nm}$, i.e., precisely the spectral which bilirubin heavily absorbs (22).

Single-strand breaks apparently are not associated with enzymatic processes because they are induced at $4^{\circ} \mathrm{C}$ in vivo as well as in vitro. This conclusion concurs with previous work with an in vivo system (3). The parallelism between results from the work in vitro and those from the work in vivo (Fig. 5) indicates that the type of DNA lesions induced by different spectral bands is not differentially affected by interactions within the living cell. This

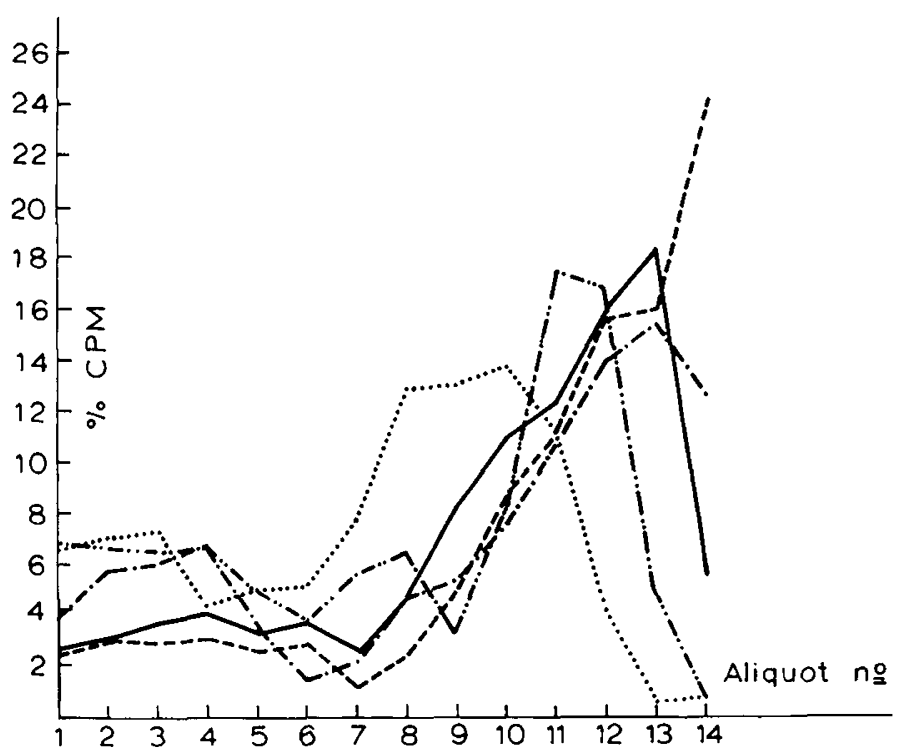

Fig. 4. Sedimentation profiles of DNA from cells exposed in situ to blue $(\cdots \cdots)$, green $(-)$ and red $(-\cdots)$ spectral bands of fluorescent light $\left(5 \times 10^{4} \mathrm{~J} / \mathrm{m}^{2}\right)$. Dark control $(---)$.

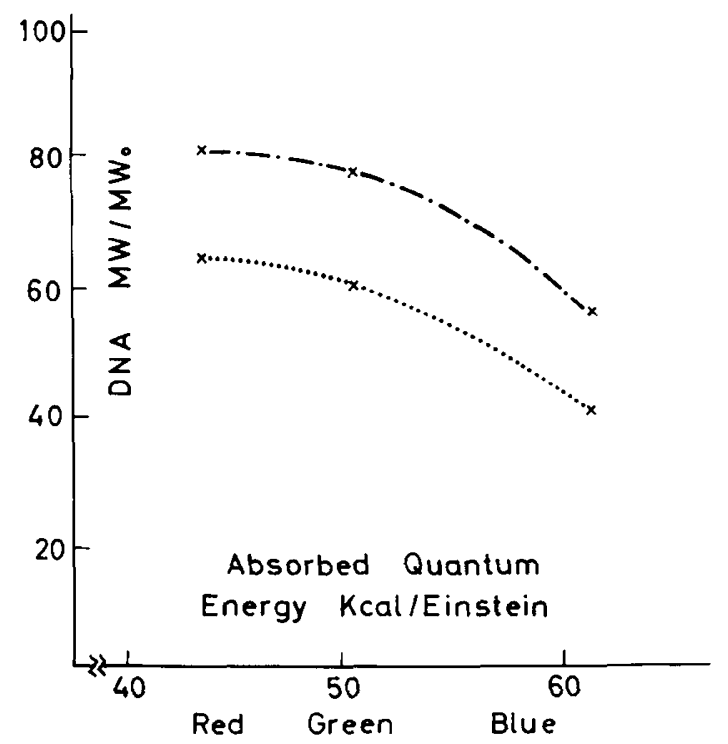

Fig. 5. Relative MW of DNA from cell alkaline lysates (- . -) and cells in situ $(\cdots \cdot)$ exposed to different spectral bands of fluorescent light plotted against the mean absorbed quantum energy of the bands. Alkaline lysates were exposed to $30 \times 10^{4} \mathrm{~J} / \mathrm{M}^{2}$ and cells in situ were exposed to 5 $\times 10^{4} \mathrm{~J} / \mathrm{m}^{2}$.

parallelism also suggests that the photosensitive moiety is either extremely well bount to the DNA molecule or it is extremely abundant within the cell or cell lysates.

Breakage in the DNA molecules by ultraviolet radiant energy escaping from the lamp has to be ruled out because: (1) transmittance through the filters, at the spectral band between 400 and $200 \mathrm{~nm}$ is 0 measured by the Carry-14 Spectrophotometer and a 356 Perkin-Elmer spectrophotometer; and (2) the differential effect of the three bands of light could not be explained. The sister chromatid exchanges frequency-absorbed quantum energy relationship is in line with that of DNA single-strand breaks (Fig. 6). There is a two-fold increase from the frequency of sister chromatid exchanges in cells exposed to $5 \times 10^{4} \mathrm{~J} / \mathrm{m}^{2}$ of red light to that of cells exposed to $5 \times 10^{4} \mathrm{~J} / \mathrm{m}^{2}$ blue light; the frequency of sister chromatid exchanges in cells exposed to green light being some place in the middle. The frequency of sister chromatid exchanges in cells not exposed to light was 2.5 sister chromatid exchanges 


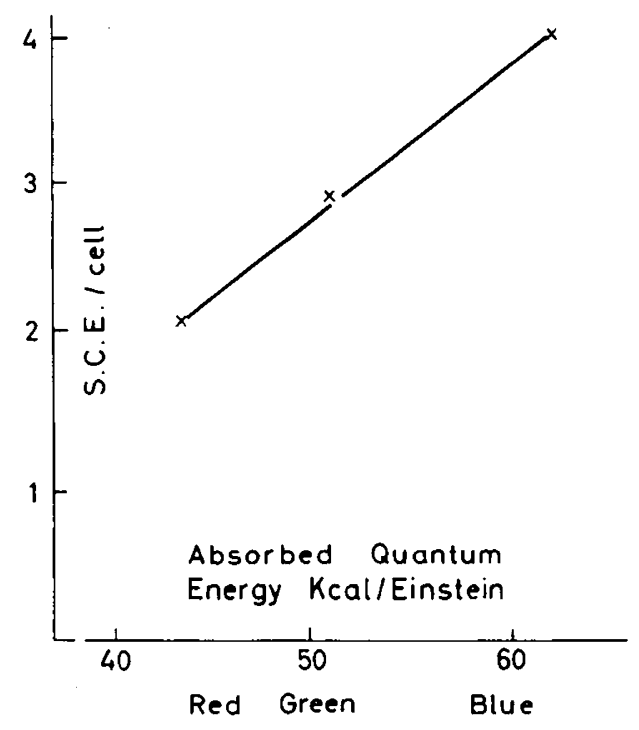

Fig. 6. Sister chromatid exchanges cell in cells exposed to different spectral bands of fluorescent light $\left(5 \times 10^{4} \mathrm{~J} / \mathrm{M}^{2}\right)$ plotted against the mean absorbed quantum energy of the bands. Three $\times 100$ mitoses per treatment.

per cell. This figure is somewhat lower, although of the same order, than those reported earlier $(13,16)$. The sister chromatid exchanges test is a powerful new method for detecting environmental mutagens-carcinogens (17). The increased frequency of sister chromatid exchanges in matter exposed to blue light coupled with a correspondingly higher frequency of induced DNA lesions suggests in inherent danger in the use of this spectral band in phototherapy.

Radioactive thymidine incorporation is also strongly affected by exposure to blue light. Exposure to green or red light does not affect the thymidine incorporation over the period examined (Fig. 7). Decreased thymidine incorporation after exposure to blue light was more apparent after the first $24 \mathrm{hr}$ of incubation after the exposuure. Our results do not reveal whether or not the observed decrease in thymidine incorporation is due to nonrepairable DNA lesions which inhibit DNA replication or to damage to other cell compounds which affect the DNA replication process. The severe decrease in thymidine incorporation observed after a $24 \mathrm{hr}$ period of incubation, i.e., two life cycles of the used cell clone, suggests a damaging process associated with the DNA replication mechanism. The possible side effects of the inhibition of DNA replication on the postreplication repair mechanisms should not be overlooked. Figure 8 presents the results on the survival of the cells exposed to $5 \mathrm{~J} / \mathrm{m}^{2}$ of fluorescent light plotted against the quantum energy. The average thymidine incorporation over a 48 -hr period, the $\mathrm{MW} / \mathrm{MW}_{0}$ of DNA, and the reverse of sister chromatid exchanges per cell exposed to the same amount of fluorescent light energy have been added into the figure. Survival shows the same tendency as all the other parameters. The damage in survival is maximum in cells exposed to blue light and minimum in cells exposed to red light. The apparent relationship between cell survival and DNA damage indicates that DNA breaks might play a role in cell lethality induced by fluorescent light (7). The presence of a strong inhibitory effect on meiosis and early development of zona-free eggs of golden hamster exposed to the blue spectral band in fluorescent light has been shown. This effect was absent in cells exposed to light of the red spectral band. An intermediate effect was present in cells exposed to light from the green spectral band (10).

These results also indicate a possible involvement of DNA breaks in the formation of sister chromatid exchanges induced by fluorescent light. Evidence supporting a possible relationship between sister chromatid exchanges and DNA lesions have also been reported by other laboratories $(18,20,26)$. However, much more

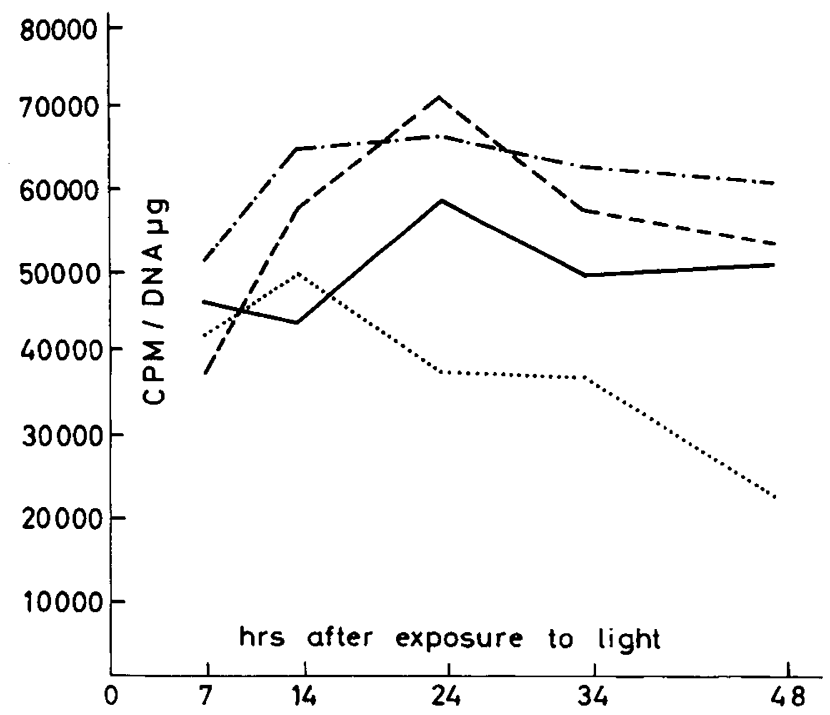

Fig. 7. Radioactive thymidine incorporation in V-79 cells exposed to blue $(\cdots \cdots)$, green $(-)$, and red $(-\cdot-)$ spectral bands of fluorescent light. Dark control (--- $)$

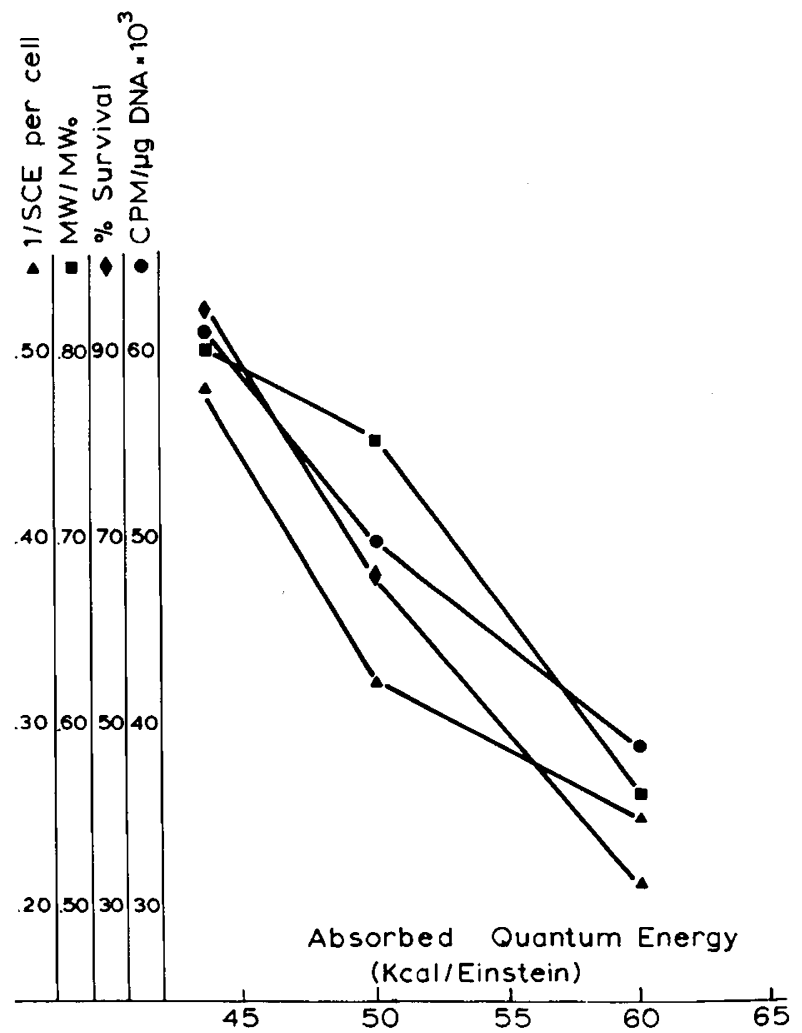

Fig. 8. Sister chromatid exchanges/cell, relative $\mathrm{MW}$, percentage of survival, and mean radioactive thymidine incorporation in cells exposed in situ to fluorescent light $\left(5 \times 10^{4} \mathrm{~J} / \mathrm{M}^{2}\right)$ of different spectral bands plotted against the mean absorbed quantum energy of the bands.

research is necessary to determine the relationship between SCE and DNA breakage (21).

In conclusion, the results of the present work on lesions induced in DNA and chromosomes by the blue spectral band of fluorescent light are in line with an early warning given by Speck and Rozenkranz (23) about the inherent potential for serious longterm consequences in the phototherapy treatment of neonatal hyperbilirubinemia. 


\section{REFERENCES AND NOTES}

1. Ames, B. N., Lee, F. D., and Durston, W. E.: An improved bacterial test system for the detection and classification of mutagens and carcinogens. Proc. Natl. Acad. Sci. U. S. A., 70: 2281 (1973).

2. Balzani, V., and Carassiti, V.: Photochemistry of Coordination Compounds. p. 6 (Academic Press, Inc., London, 1970).

3. Bradley, M. O., and Sharkey, N. A.: Mutagenicity and toxicity of visible fluorescent light to cultured mammalian cells. Nature (Lond), 266: 724 (1977).

4. Burton, K.: Determination of DNA concentration with diphenylamine. Methods Enzymol., 12: 163 (1968).

5. Eisenstark, A.: Mutagenic and lethal effects of visible and near ultraviolet light on bacterial cells. Adv. Genet. 16: 167 (1971)

6. Elkind, M. M.: Sedimentation of DNA released from chinese hamster cells. Biophys. J., ll: 502 (1971).

7. Elkind, M. M., and Han, A.: DNA single-strand lesions due to "sunlight" and UV light: A comparison of their induction in chinese hamster and human cells, and their fate in chinese hamster cells. Photochem. Photobiol., 27: 717 (1978).

8. Forbes, P. D.: Influence of long wave UV on photocarcinogenesis, Abst. Am. Soc. Photobiol., 136 (1973).

9. Friendman, C. A., Kohn, K. W., and Erickson, L. C.: DNA chain growing during replication of asynchronus L1210 cells. Alkaline sedimentation studies. Biochemistry, 14: 4018 (1975).

10. Hirao, Y., and Yanagimachi, R.: Detrimental effect of visible light on meiosis of mammalian eggs in vitro. J. Exp. Zool., 206: 365 (1978).

11. Hsie, A. W., Li, A. P., and Machanoff, R.: A fluence response study of lethality and mutagenicity of white, black and blue fluorescent light sunlamp and sunlight irradiation in chinese hamster ovary cells. Mutat. Res., 45: 333 (1977)

12. Hollaender, A.: Effect of long ultraviolet and short visible radiation (3500-4900 $\AA$ ) on E. coli. J. Bacteriol., 46: 531 (1943).

13. Ikushima, $T$., and Wolff, $S$.: Sister chromatid exchanges induced by light flashes to 5-bromodeoxyuridine and 5-iododeoxyuridine substituted chinese hamster chromosomes. Exp. Cell Res., 87: 15 (1974).

14. Jostes, R. E., Dewey W. C., and Hopwood, L. E.: Mutagenesis by fluorescent light in mammalian cell cultures. Mutat. Res., 42: 139 (1977).

15. Lehman, A. R.: Postreplication repair of DNA in ultraviolet irradiated mammalian cells. J. Mol. Biol., 66: 319 (1972).
16. Monticone, R. E., and Schneider, E. L.: Induction of sister chromatid exchanges in human cells by fluorescent light. Mutat. Res., 59: 215 (1979).

17. Palcic, B., and Skarsgard, L. D.: The effect of oxygen on DNA single-strand breaks produced by ionizing radiation in mammalian cells. Int. J. Radiat. Biol., 21: 417 (1972).

18. Perry, P., and Evans H. J.: Cytological detection of mutagen-carcinogen exposure by sister chromatid exchange. Nature (Lond.), 258: 121 (1975).

19. Puck, T. T., and Kao, F. T.: Genetic of somatic mammalian cells. V. Treatmen with 5-bromodeoxy uridine and visible light for isolation of nutritionally deficient mutants. Proc. Natl. Acad. Sci. U. S. A., 58: 1227 (1967)

20. Sasaki, M. S.: Sister chromatid exchange and chromatid interchange as possible manifestation of different DNA repair processes. Nature (Lond.), 269: 623 (1977).

21. Schneider, E. L., Tice, R. R., and Kram, D.: Bromodeoxyuridine differential chromatid standing technique. Methods Cell Biol., 20: 379 (1978).

22. Sisson, T. R. C.: Visible light therapy of neonatal hyperbilirubinemia. Photochem Photobiol. Rev., 1: 241 (1976).

23. Speck, W. T., and Rozenkranz, H. S. Intracellular DNA-modifying activity of high intensity light. Pediatr. Res., 10: 553 (1976).

24. Sylvania Engineering Butletin 0-238, Spectral energy distribution curves of Sylvania F40T 12 fluorescent lamps.

25. Webb, R. B., and Malina, M. M.: Mutagenesis in Escherichia coli by visible light. Science (Wash. D. C.), 136: 1104 (1967).

26. Wolff, S., Bodycote, J. and Painter, R. B.: Sister chromatid exchanges induced in chinese hamster cells by UV irradiation of different stages of the cell cycle: The necessity for cells to pass through S. Mutat. Res., 25: 73 (1974).

27. Zigman, S.: Near UV light and cataracts. Photochem. Photobiol., 26: 437 (1977)

28. The authors We are grateful to Dr. C. Bartsokas, M.D., of the Department of Pediatrics, Medical School, Athens, for helpful discussions and criticisms during the preparation of the manuscript and to A. S. Gourgou for assistance at the laboratory.

29. Requests for reprints should be addressed to: Dr. E. G. Sideris, Department of Biology, Nuclear Research Center Demokritos, Aghia Paraskevi, Athens, Greece.

30. Received for publication March 10, 1980

31. Accepted for publication November 6, 1980. 